\title{
Intravascular Large B-Cell Lymphoma Presenting as Dementia and Hemolytic Anemia
}

\author{
Alexander Baraniskin ${ }^{\mathrm{a}} \quad$ Andreas Jähnert $^{\mathrm{a}}$ Guido Ahle $^{\mathrm{b}} \quad$ Anja Theile $^{\mathrm{c}}$ \\ Hans Kretzschmar ${ }^{d}$ Wolff Schmiegel ${ }^{a}$ Roland Schroers ${ }^{a}$ \\ a Department of Medicine, Hematology and Oncology, \\ ${ }^{\mathrm{b}}$ Department of Neurology, \\ ${ }^{c}$ Institute of Pathology, Ruhr-University of Bochum, \\ ${ }^{\mathrm{d}}$ Institute of Neuropathology, Ludwig-Maximilians University, Munich, Germany
}

\section{Key Words}

Intravascular large B-cell lymphoma (IVL) - Dementia . Hemolytic anemia · Spherocytosis - Osmotic resistance

\section{Summary}

Background: Intravascular lymphoma (IVL) is an uncommon disease characterized by atypical lymphoid cells growing inside the lumina of small vessels. The diversity of clinical presentation due to possible involvement of multiple organs often complicates its diagnosis. Case Report: Here, we report on a case of IVL with rapidly progressive dementia and Coombs-negative hemolytic anemia. Interestingly, the erythrocytes exhibited a decreased osmotic resistance. Bone marrow histopathology revealed increased erythropoiesis and, finally, a small monoclonal B lymphocyte population. Cerebral magnetic resonance imaging (MRI) demonstrated few micro-bleedings. Computed tomography (CT) showed bilateral ground-glass opacity of the lungs. Within a few days, the patient developed respiratory failure and died. On post-mortem examination, intravascular large B-cell lymphoma with almost complete infiltration of the brain and lungs was diagnosed. Conclusion: IVL should be considered early in situations of unexplained neuropsychiatric disease along with markedly elevated levels of lactic dehydrogenase, anemia, and hemolysis.

\section{Schlüsselwörter \\ Lymphom, intravaskuläres · Demenz · Anämie, hämolytische $\cdot$ Sphärozytose $\cdot$ Osmotische Resistenz}

\section{Zusammenfassung}

Hintergrund: Das intravaskuläre Lymphom (IVL) ist eine seltene Erkrankung, die sich durch ein intravaskuläres Wachstum von lymphatischen Tumorzellen auszeichnet. Die Vielfalt der Symptome und die Beteiligung multipler Organe erschweren die Diagnosestellung. Fallbericht: Wir berichten über einen Patienten, bei dem es infolge eines IVL zu einer rasch progredienten Demenz und einer Coombs-negativen hämolytischen Anämie kam. Die Erythrozyten wiesen interessanterweise eine deutlich verminderte osmotische Resistenz auf. Die Untersuchung des Knochenmarks zeigte eine gesteigerte Erythropoese und schließlich eine kleine Population monoklonaler B-Lymphozyten. In einer Magnetresonanztomografie (MRT) des Schädels fanden sich cerebrale Mikroblutungen. Computertomografisch zeigten sich im Verlauf milchglasige Infiltrationen in beiden Lungen. Innerhalb weniger Tage verstarb der Patient infolge einer respiratorischen Globalinsuffizienz. Die Obduktion zeigte eine beinahe vollständige pulmonale und cerebrale Infiltration durch ein IVL. Schlussfolgerung: Ein IVL sollte bei unklaren neuropsychiatrischen Erkrankungen, die mit einer erhöhten Laktatdehydrogenase-Konzentration und einer hämolytischen Anämie einhergehen, frühzeitig diagnostisch in Betracht gezogen werden.

\begin{tabular}{ll}
\hline KARGER & $\oplus$ 2010 S. Karger GmbH, Freiburg \\
Fax +497614520714 & Accessible online at: \\
$\begin{array}{l}\text { Information@Karger.de } \\
\text { www.karger.com }\end{array}$ & www.karger.com/onk
\end{tabular}




\section{Introduction}

Intravascular lymphoma (IVL), also known as angiotropic large-cell lymphoma, is an uncommon systemic disease characterized by atypical lymphoid cells growing inside the lumina of small vessels [1]. The distinctive microscopic feature of IVL is occlusion of blood vessels by neoplastic non-adherent lymphatic cells. The malignant cells are remarkably restricted to the intraluminal space and are completely lacking in adjacent tissues. The precise mechanisms responsible for this distinctive behavior are largely unknown $[2,3]$. Frequently, massive lymphoma proliferation causes thromboembolism with subsequent ischemic infarcts or hemorrhages. IVL is predominantly of B-cell origin, although cases of T-cell IVL have been reported $[1,2]$. The disease occurs in a wide age range, with no predilection for sex [4]. The clinical symptoms of the disease are dependent on the specific organ involvement [5]. The brain and skin are the most commonly involved sites; nodal disease is rare [4]. IVL goes along with poor performance status, B-symptoms, anemia, and high lactate dehydrogenase serum levels [2].

Here, we report on a patient with IVL primarily presenting with progressive dementia and hemolytic anemia. The diagnosis was obscured by an elevated $\tau$-protein cerebrospinal fluid (CSF) level mimicking Creutzfeld-Jacob disease. Strikingly, a Coombs-negative hemolytic anemia was found and was shown to be associated with a decreased osmotic resistance of red blood cells (RBCs). Following rapid disease progression with respiratory failure, the patient died before the correct diagnosis was made.

\section{Case Report}

A 76-year-old man was transferred to our hospital after a 2-week stay in a community hospital due to progressive mental deterioration. Chronic fatigue, cephalgias, and cognitive impairment without B-symptoms had occurred a few months before. Reasons for emergency admission were sudden onset of disorientation and aphasia. An early cerebral computed tomography (CT) scan appeared normal. Since the symptoms spontaneously resolved during $6 \mathrm{~h}$, a preliminary diagnosis of transient ischemic attack (TIA) was made. However, blood tests revealed a severe hemolytic anemia. Despite RBC transfusions and prednisone, the hemoglobin levels remained low and, eventually, the patient was transferred with deteriorating neuropsychiatric symptoms.

Upon admission, we saw a mopish patient, only intermittently responsive to questions with one-word answers. On physical examination, the patient showed jaundice but was otherwise normal (no focal neurological deficits, no peripheral lymphadenopathy, no enlargement of liver/spleen). Blood tests revealed macrocytic anemia (hemoglobin $102 \mathrm{~g} / \mathrm{l}$, mean cellular volume (MCV) $112 \mathrm{fl}$, mean corpuscular hemoglobin concentration $(\mathrm{MCHC}) 32 \mathrm{~g} / \mathrm{dl})$, minor leukocytosis $\left(14 \times 10^{9} / 1\right)$ but normal platelet counts $\left(227 \times 10^{9} / 1\right)$. Lactic dehydrogenase was markedly elevated $(1126 \mathrm{U} / 1)$, as were unconjugated bilirubin $(3.3 \mathrm{mg} / \mathrm{dl})$ and the reticulocyte counts (13\%; reticulocyte production index 8.6). C-Reactive-protein and results of other blood tests, including concentrations of ferritin, vitamin $\mathrm{B}_{12}$, and folate, and tests for kidney, liver, thyroid function, and autoimmune disease were normal. Coombs' test and flow-cytometric analysis of RBCs for
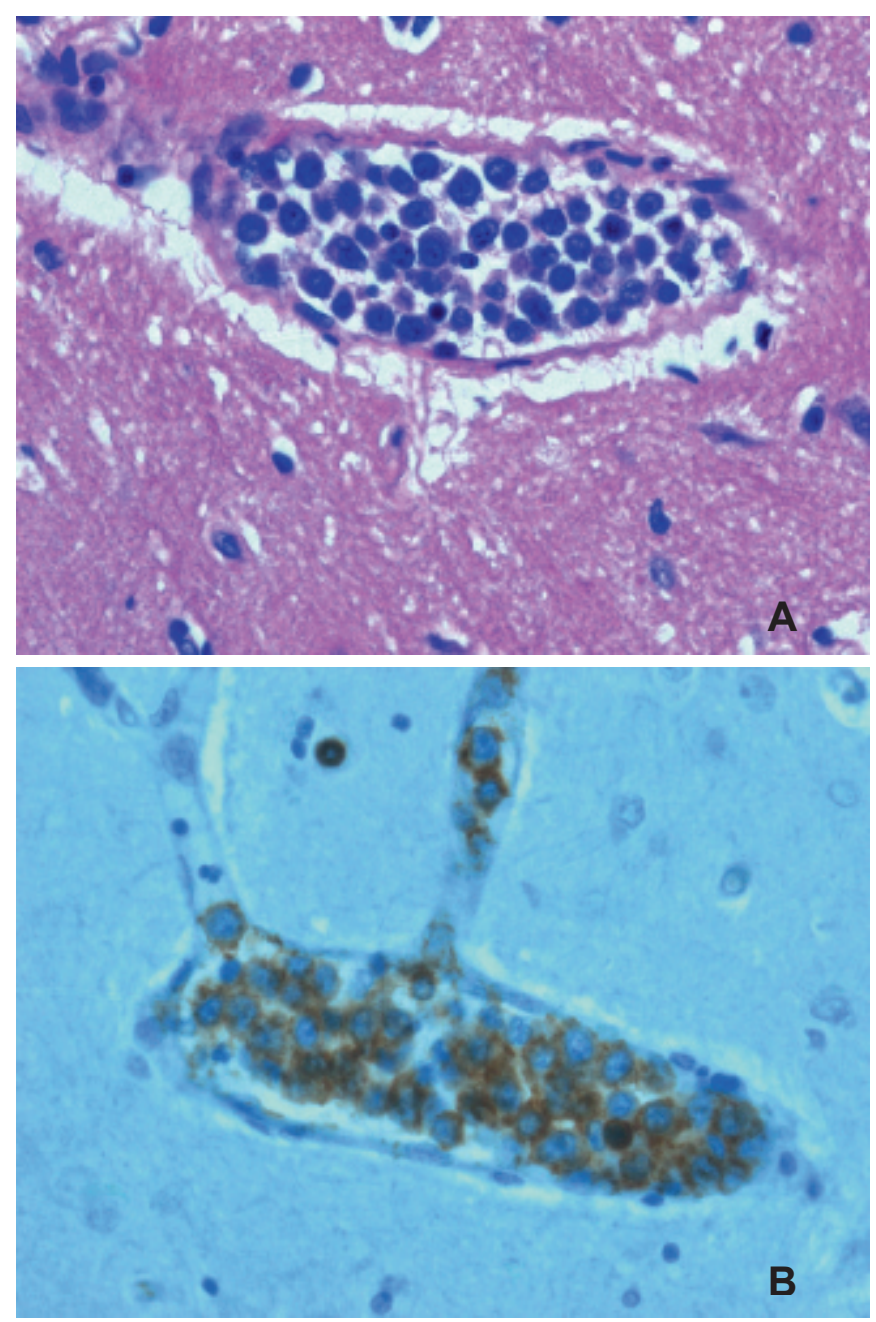

Fig. 1. Intravascular large B-cell lymphoma. (A) Lymphoma cells fill the small vessels of a post-mortem brain specimen (hematoxylin-eosin, original magnification $\times 400)$. (B) Corresponding immunohistochemical staining for human CD20 (original magnification $\times 400$ ).

surface-bound immunoglobulin gave negative results. Paroxysmal nocturnal hemoglobinuria (PNH) was excluded by flow-cytometric normal expression of glycosylphosphatidylinositol (GPI)-anchored proteins. In peripheral blood smears, an erythrocyte fraction appeared small with lack of the central pallor. The osmotic resistance of the erythrocytes was markedly reduced. Bone marrow aspirates appeared normal, except for an increased erythropoiesis. Flow cytometry of the bone marrow cells did not show an abnormal B-lymphocyte population. However, histopathology gave a suspicion of a small atypical lymphocyte population. Initial chest radiography and abdominal ultrasound were inconspicuous. Cerebral magnetic resonance imaging (MRI) including angiography ruled out sinus venous thrombosis but exhibited few micro-bleedings in both hemispheres. Electroencephalography (EEG) revealed a theta activity, indicating diffuse cerebral dysfunction. The CSF was normal, except for increased $\tau$-protein levels ( $>1000 \mathrm{pg} / \mathrm{ml}$; normal $<445 \mathrm{pg} / \mathrm{ml})$. Although the patient initially had no signs of respiratory disease, he rapidly developed respiratory failure necessitating ventilatory support 5 days after transfer to our hospital. A CT scan of the chest at that time showed bilateral ground-glass opacity of the lungs. Despite intensive antibiotic and anti-inflammatory treatment, the patient succumbed before a biopsy of the lungs could be performed. 
On post-mortem examination, the cause of death was multiple organ failure induced by intravascular large B-cell lymphoma with almost complete infiltration of the brain and lungs. In brain tissue specimens, atypical lymphocytes were demonstrated within arterioles, venules, and capillaries. The capillaries were filled with lymphoma cells superficially resembling leukemia cells or cells derived from undifferentiated carcinoma (fig. 1A). Immunohistochemical studies demonstrated that the tumor cells expressed the common leukocyte antigen and the B-cell marker CD20 (fig. 1B). On the contrary, the tumor cells exhibited no immunoreactivity for CD30, CD10, and for T-cell markers (CD3, CD5). The proliferation marker Mib-1 showed a nuclear reaction pattern in the majority of the neoplastic cells. The adhesion molecules CD29 and CD54 were both not expressed. In addition to the brain vessels, the lung vasculature was ubiquitously filled with lymphoma cells, and the bone marrow was infiltrated by lymphoma cells (3\% of nucleated cells) as well. Other organs including lymph nodes, spleen, liver, and kidneys were pathologically normal.

\section{Discussion}

Intravascular lymphoma (IVL) is defined as the intravascular proliferation of clonal lymphocytes without involvement of the surrounding organ parenchyma [1]. The intravascular growth pattern has been suggested to be secondary to a loss of homing receptors, such as CD29 and CD54. Multiple organs may be involved and a variety of clinical presentations have been described until today $[1,6]$.

Rather frequently (40-70\%) the brain is involved and patients with cerebral IVL may present with neuropsychiatric symptoms, sometimes mimicking Creutzfeld-Jacob disease with increased 14-3-3-protein or $\tau$-protein CSF levels, as observed in our patient [7]. $\tau$-Protein and 14-3-3-protein are markers related to sub-acute destruction of neurons [7, 8]. Patients with IVL may also present with unspecific symptoms including fever of unknown origin, night sweats, fatigue, and general malaise. Other clinical manifestations involve the skin, with the cutaneous variant of IVL probably carrying a more favorable diagnosis [4]. Involvement of the lungs at autopsy can be found in up to $60 \%$ of patients [5]. Other frequent manifestations of IVL are hepatosplenomegaly (77\%) and bone marrow infiltration (75\%) [3]. Although IVL represents a clonal proliferation of lymphocytes, it is uncommon to find significant lymphadenopathy. Despite its intravascular growth pattern, IVL is not often $(<10 \%)$ associated with peripheral blood involvement [7].

Anemia (70\%) and increased serum lactate dehydrogenase $(90 \%)$ are the most common laboratory findings [4]. The initial findings in our patient with IVL were dementia and Coombsnegative hemolytic anemia. Interestingly, hemolysis and spherocytosis were associated with decreased osmotic resistance of the RBCs. The patient had no past medical history or family history of hemolytic anemia. The finding of a hemolytic anemia in IVL mimicking hemolysis due to erythrocyte membrane instability (such as hereditary spherocytosis) has not been reported yet. A potential mechanism causing decreased resistance of erythrocytes is mechanical damage to the cells while they pass through capillaries filled with atypical lymphocytes. In contrast to micro-angiopathic hemolytic anemia such as thrombotic thrombocytopenic purpura (TTP) and hemolytic uremic syndrome (HUS), erythrocyte damage in IVL appears different, as indicated by the lack of the fragmented erythrocytes in peripheral blood smears. In our case, neither hemophagocytosis in the bone marrow biopsies nor clinical signs characteristic of hemophagocytic syndrome (unexplained fever, hepatosplenomegaly, or thrombocytopenia) were observed.

IVL is a difficult diagnosis to make ante mortem, because of its variable clinical presentation with frequent lack of overt hematopoietic organ involvement. IVL often shows rapid progression and poor survival without instant therapy. Nonetheless, there are some points that can be helpful in the diagnosis of IVL. Accordingly, IVL should be considered in patients with unexplained neuropsychiatric and/or respiratory disease along with markedly elevated levels of lactic dehydrogenase and anemia. In this situation, whole-body imaging combined with instant biopsy of involved organs is mandatory [3].

In most cases, IVL is disseminated at diagnosis and warrants treatment with systemic therapy. There are no large randomized trials regarding this rare entity. Therapy follows treatment recommendations in more common lymphoma subtypes. Frequently, anthracycline-based chemotherapy regimens such as cyclophosphamide, doxorubicin, vincristine, and prednisone (CHOP) are administered. The addition of the monoclonal antibody rituximab (R-CHOP) in IVL with a B-cell immunophenotype significantly improves the prognosis as compared to treatment with chemotherapy (CHOP) alone: overall survival at 3 years, $89 \%$ vs. $38 \%(p=0.01)$ [9].

In summary, IVL is a rare disease often presenting with unspecific symptoms and signs. In order to improve disease prognosis, early diagnosis by means of imaging-guided biopsy of involved organs followed by intensive chemoimmunotherapy is essential. In some cases, however, IVL is not diagnosed ante mortem due to the solely intravascular lymphoma growth pattern and a fulminant clinical course.

\section{Conflict of Interest}

The authors have no conflict of interest to declare. 


\section{References}

1 Nakamura S, Ponzoni M, Campo E: Intravascular large B-cell lymphoma; in Swerdlow SH, Campo E, Harris NL, Jaffee ES, Pileri S, Stein H, Thiele J, Vardiman JW (eds): Pathology and Genetics of Tumours of Haematopoietic and Lymphoid Tissues. Lyon, IARC Press, 2007, pp 252-253.

2 Ferreri AJ, Dognini GP, Campo E, Willemze R, Seymour JF, Bairey O, Martelli M, De Renz AO, Doglioni C, Montalban C, Tedeschi A, Pavlovsky A, Morgan S, Uziel L, Ferracci M, Ascani S, Gianelli U, Patriarca C, Facchetti F, Dalla LA, Pertoldi B Horvath B, Szomor A, Zucca E, Cavalli F, Ponzoni $\mathrm{M}$ : Variations in clinical presentation, frequency of hemophagocytosis and clinical behavior of intravascular lymphoma diagnosed in different geographical regions. Haematologica 2007;92:486-492.

3 Murase T, Yamaguchi M, Suzuki R, Okamoto M, Sato Y, Tamaru J, Kojima M, Miura I, Mori N, Yoshino T, Nakamura S: Intravascular large B-cell lymphoma (IVLBCL): a clinicopathologic study of 96 cases with special reference to the immunophenotypic heterogeneity of CD5. Blood 2007;109: 478-485.
4 Ponzoni M, Ferreri AJ, Campo E, Facchetti F, Mazzucchelli L, Yoshino T, Murase T, Pileri SA, Doglioni C, Zucca E, Cavalli F, Nakamura S: Definition, diagnosis, and management of intravascular large B-cell lymphoma: proposals and perspectives from an international consensus meeting. J Clin Oncol 2007;25:3168-3173.

5 Snyder LS, Harmon KR, Estensen RD: Intravascular lymphomatosis (malignant angioendotheliomatosis) presenting as pulmonary hypertension. Chest 1989;96:1199-1200.

6 Ferreri AJ, Campo E, Seymour JF, Willemze R, Ilariucci F, Ambrosetti A, Zucca E, Rossi G, LopezGuillermo A, Pavlovsky MA, Geerts ML, Candoni A, Lestani M, Asioli S, Milani M, Piris MA, Pileri S, Facchetti F, Cavalli F, Ponzoni M: Intravascular lymphoma: clinical presentation, natural history, management and prognostic factors in a series of 38 cases, with special emphasis on the 'cutaneous variant'. Br J Haematol 2004;127:173-183.
7 Albrecht R, Krebs B, Reusche E, Nagel M, Lencer R, Kretzschmar HA: Signs of rapidly progressive dementia in a case of intravascular lymphomatosis. Eur Arch Psychiatry Clin Neurosci 2005;255:232235.

8 Berg D, Holzmann C, Riess O: 14-3-3 proteins in the nervous system. Nat Rev Neurosci 2003;4:752762

9 Ferreri AJ, Dognini GP, Bairey O, Szomor A Montalban C, Horvath B, Demeter J, Uziel L, Soffietti R, Seymour JF, Ambrosetti A, Willemze R, Martelli M, Rossi G, Candoni A, De Renzo A, Doglioni C, Zucca E, Cavalli F, Ponzoni M: The addition of rituximab to anthracycline-based chemotherapy significantly improves outcome in 'Western' patients with intravascular large B-cell lymphoma. Br J Haematol 2008;143:253-257. 